\title{
Examining the Effects of Learning Organization Discipline on Employee Readiness and Organizational Commitment
}

\author{
Hamidah Nayati Utami* \\ Department of Business Administration \\ Universitas Brawijaya \\ Malang, Indonesia \\ *hamidahn@ub.ac.id
}

\begin{abstract}
Learning Organization is an organization whose members continuously improve or expand their abilities to create the results they really want where new and expansive thinking patterns are cultivated, aspirations are developed, and its members continuously learn how to learn together. Learning organization is important aspect to enhance the development of the learning process in higher education, especially in the education 4.0 era. The aim of this empirical study was to examine the effect of learning organizational discipline on employee readiness and organizational commitment. To achieve this objective the data was collected using an online survey from 96 academic staff at Public University in Indonesia. The collecting data technique used questionnaires with a 5-point Likert scale ranging from 1 (strongly disagree) to 5 (strongly agree). a 5-point Likert scale ranging from 1 (strongly disagree) to 5 (strongly agree). This research was using quantitative method, PLS, and SPSS. The finding indicate that 3 hypotheses have significant positive effect. Learning organization discipline has significant positive effect on employee readiness, learning organization discipline has significant positive effect on organizational commitment, and employee readiness has significant positive effect in organizational commitment. University needs to develop organizational commitment and employee readiness by adopting learning organization discipline.
\end{abstract}

Keywords - organizational commitment, readiness, learning organization, staff academic, university

\section{INTRODUCTION}

The emergence of education 4.0 is a response to changing needs due to the 4.0 industrial revolution, where humans and technology are related to each other to create new opportunities in creative and innovative ways. Aberseck argues that education 4.0 will bring about changes and new challenges for the world of education [1]. This is in line with the opinion of Dunwill which states that technological advances continue to change teaching methods and learning governance [2]. In addition, Education 4.0 provides unlimited opportunities to organize learning at any time. The learning and knowledge of this era is a new learning system that allows each individual to acquire life-long knowledge and skills [3]. Therefore, the ability to adapt to environmental changes needs to be carried out by all education stakeholders.

Higher education requires thorough preparation in facing the new era of education and the Ministry of Education and Culture's program regarding an independent campus. Lecturers and employees are required to always improve their competence in order to be able to keep up with changes, especially those related to the use of technology as a support in the educational process. However, if seen from conditions in the field, not all components are ready to face the changes. One of the efforts that can be taken is by implementing a learning organization. By transforming into a learning organization, the organization can create a continuous and comprehensive learning culture from the individual to the organizational level. This is reinforced by the learning organization paradigm put forward by Senge [4] that learning organizations are organizations whose members continuously improve or expand their ability to create the results they really want where new and expansive thinking patterns are grown, shared aspirations are allowed. freely, and its members are continuously learning how to learn together. A large number of learning organizations consider the Senge model to be the most suitable framework for organizational development for both business organizations and educational organizations [5].

If it is related to the context of the industrial revolution and education 4.0, the existence of learning organizations develops a pattern of relationships between colleagues, superiors and subordinates as a process of human resource literacy so that they are able to interact well, are not rigid, and have character [6]. Education 4.0 and the Independent Campus require a level of readiness and commitment to carry out an educational process that uses new learning principles that intersect with technology and freedom of learning. Theoretically, work readiness is understood as a condition that indicates the existence of harmony between physical, mental and experiential maturity so that individuals have the ability to carry out certain activities in relation to work [7]. Some factors 
that influence the level of a person's work readiness are maturity factors, intelligence factors, skills factors, ability factors, and environmental factors [8]. Environment becomes a factor that determines a person's level of readiness because basically when a person works, he is required to adapt to the values, norms, and culture that are all contained in the environment.

The study of Learning Organization and work readiness discusses how an organization with a culture and learning principles is able to encourage its employees to have work readiness in the form of readiness to change for the better [9]. For example, in the concept of Learning Organization, transformational leaders influence employee performance through providing role models in working with various innovative and solution actions that they issue [10]. Indirectly, this makes employees have the readiness to change for the better as is done by their leaders

Changes in technology and demands for implementing educational policies require universities to continue to learn and motivate their employees to have a high work commitment. Based on the literature review, commitment is understood as something related to the meaning of organizational members for their work and how individuals carry out their duties in an organization [11]. A previous study even explained that employee readiness had a positive and significant effect on employee commitment through organizational support as a moderating variable [12]. In these results, the organizational support in question opens opportunities for further research related to the Learning Organization. However, there has not been any research that also examines these three variables.

Based on the explanation above, the objectives of this study are: 1. to examine and explain the effect of organizational learning on employee readiness, 2. to examine and explain the effect of employee readiness on organizational commitment, and 3 to examine and explain the effect of employee readiness on organizational commitment.

This paper is organized as follows, Section I contains the introduction of this study, Section II contain the related work of the study, Section III contain some measures of method. Section IV describe result and discussion. Section V concludes research work with future directions.

\section{RELATED WORK}

The definition of learning organization first emerged from Argyris [13]. According to Agyris, learning is only used as a process of detection (Detecting) and correction (Correcting) [13]. However, in 1990 by referring to the opinions and concepts put forward by Argyris, Peter Senge expressed his ideas about learning organizations in a book entitled "The Fifth Discipline the Art and Practice of the Learning Organization" [4]. Furthermore, the discussion of organizational learning becomes a discussion that is widely studied and applied by various parties who consider that the learning organization paradigm needs to be applied to create a change in the organization. In defining organizational learning, there are several views put forward by experts, which are the opinions expressed by Senge [4] and Marquardt [14] as follows:

According to Senge's [4] opinion, a learning organization is an organization where each member continuously improves or expands their ability to create the results they really want, where new and expansive thinking patterns are grown, shared aspirations are left free, and members - its members are continuously learning how to learn together. According to the opinion of Marquardt [14] learning organization is understood as an organization that continuously improves its capacity and learns together and transforms to be better, collect, organize and use knowledge for organizational success.

Based on the various opinions above, a learning organization can be understood as an organization whose members carry out continuous and comprehensive learning with the aim of being better for organizational success. According to Dodgson [15] there are three basic reasons why learning organization becomes important in the midst of the rapid development of science and technology, 1) because environmental changes require organizations to always adapt and build new strategies, 2) these changes bring uncertainty which requires organizations to always ready to learn many new things, 3) Learning organization is a dynamic concept that causes an organization to undergo changes continuously.

Meanwhile, studies on Learning Organization and work readiness are more likely to be dominated by how an organization with a culture and learning principles encourages its employees to have work readiness in the form of new readiness.

Based on the explanation above, formulation of hypothesis is:

- Hypothesis 1: Learning Organization has a positive effect on employee readiness.

- Hypothesis 2: Learning organization has a positive effect on work Commitment.

- Hypothesis 3: Employee readiness has a positive effect on work Commitment.

\section{Methodology}

This study used explanatory research to find the causal relationship between the variables. The unit of analysis was lecturer at Public University in Indonesia. Sample technique for this study was determined by using the proportionate random sampling method with a total sample of 96 lecturer. The collecting data technique used questionnaires in 2020. Respondents were required to indicate agreement with the importance of each statement on a 5-point Likert scale ranging from 1 (strongly disagree) to 5 (strongly agree). The questionnaires were pre-tested and revised. Questions in the questionnaire were based on previous studies and discussions with a number of experts. Data analyzed by partial linear regression. 


\section{RESUltS AND DisCUSSION}

\section{A. Results}

Table 1 presents descriptive and mean for the learning organization items. Based on the respondents' answers to the Learning Organization variables listed in Table 1, it consists of 20 question items and 5 indicators. This instrument was adapted from the research of Abbasi, Taqipour, and Farhadian [5]. The Shared Vision indicator is an indicator that has the greatest mean score, namely 4.22. Meanwhile, other indicators such as Mental Model have a mean value of 4.21, T Learning 4.19, System Thinking 4.17 and personal mastery of 3.90. For the mean score of the learning organization variable is 4.13 . The range of question item mean between 3,75 until 4,44. The response that has the highest mean is Trust a variety of useful information to solve problems. Information is one of factor that useful to solve problem in the organization. But they need more program to develop their personality.

\section{TABLE I. MEAN SCORE OF LEARNING ORGANIZATION}

\begin{tabular}{|c|c|}
\hline Learning Organization Measurement & Mean \\
\hline Consideration of customer needs in the curriculum & 4.18 \\
\hline Consideration of Environmental impact in the curriculum & 4.24 \\
\hline Consideration of program sustainability aspects & 4.07 \\
\hline Consistency with government policy & 4.21 \\
\hline Indicator 1: System Thinking & 4.17 \\
\hline Lecturer personality development & 3.75 \\
\hline Increasing the professionalism of lecturers & 4.11 \\
\hline Bridging the gap between reality and expectations & 3.76 \\
\hline Increasing skills and knowledge in teaching & 3.99 \\
\hline Indicator 2: Personal Mastery & 3.90 \\
\hline Pay attention to the suitability of goals & 4.04 \\
\hline Actively exploring new ideas & 4.08 \\
\hline Awareness that beliefs will influence actions & 4.33 \\
\hline Can explain the reasons for action & 4.39 \\
\hline Indicator 3: Mental Model & 4.21 \\
\hline Help realize the vision and goals of the organization & 4.41 \\
\hline $\begin{array}{l}\text { Aligning personal goals with the vision and goals of the } \\
\text { organization }\end{array}$ & 4.18 \\
\hline $\begin{array}{l}\text { Comfortable sharing ideas about the organization's vision with } \\
\text { colleagues }\end{array}$ & 4.22 \\
\hline $\begin{array}{l}\text { Service changes consider the impact on the organization's vision } \\
\text { and goals }\end{array}$ & 4.10 \\
\hline Indicator 4: Shared vision & 4.22 \\
\hline Freedom to ask coworkers & 4.04 \\
\hline Involvement in organizational development activities & 4.15 \\
\hline Share information with colleagues & 4.14 \\
\hline Trust a variety of useful information to solve problems & 4.44 \\
\hline Indicator 5: Team learning & 4.19 \\
\hline Variable: Learning Organization & 4,13 \\
\hline
\end{tabular}

The mean score of respondents' answers to the work readiness variable is presented in Table 2. Measurement of work readiness variables is taken from Robbins [16] and Mansoor's [3] research results with 6 question items and 2 indicators. The mean score of Ability indicator is 4.20 and Willingness is 4.12. Meanwhile, the mean score of all work readiness variables was 4.16 .

The range of question item mean between 4,03 until 4,25. The highest mean is willingness to make a change of evaluation or examination, and the lowest mean score is Willingness to teach in various places Information is one of factor that useful to solve problem in the organization. But they need more program to develop their personality.

TABLE II. MEAN SCORE OF EMPLOYEE READINESS

\begin{tabular}{|c|c|}
\hline Measurement & Mean \\
\hline Willingness to teach at various times & 4.06 \\
\hline Willingness to teach in various places & 4.03 \\
\hline Willingness to make changes to the examination model & 4.28 \\
\hline Indicator 1: Willingness & 4.12 \\
\hline Ability to provide personal learning (Personalized Learning) & 4.15 \\
\hline The ability to teach using Project-based methods & 4.22 \\
\hline Ability to carry out field learning (Field Experience) & 4.25 \\
\hline Indicator 2: Ability & 4.20 \\
\hline Variable: Employee Readiness & 4.16 \\
\hline
\end{tabular}

Table 3 presents mean score for the Work Commitment items with the range of mean between 3,90 until 4,21. These variables consists of 15 question items and 3 indicators. This instrument was adapted from the research of Mayer and Allen [17]. Continuance indicator is an indicator that has the greatest mean score, namely 3,77. And the lowest indicator is Affective commitment. If this mean score compared with the two previous variables, the mean score of this variable is the lowest.

TABLE III. MEAN SCORE OF WORK COMMITMENT

\begin{tabular}{|c|c|}
\hline Measurement & Mean \\
\hline Will spend the rest of his career in this organization & 4.54 \\
\hline Enjoy discussing the organization with outsiders & 4.19 \\
\hline Feel like a "part of the family" in organization & 1.80 \\
\hline Have a strong sense of belonging to the organization & 1.67 \\
\hline Emotionally attached to the organization & 1.56 \\
\hline Indicator 1: Affective & 3,05 \\
\hline It's hard to leave this organization & 3.82 \\
\hline It's hard to develop a career outside & 3.60 \\
\hline Keep working at this job because there is no other job. & 3.91 \\
\hline Keep working here because there is no other alternative & 2.57 \\
\hline Keep working here because you have good prospects & 4,31 \\
\hline Indicator 2: Normative & 3,09 \\
\hline Every person who works must be loyal to his workplace. & 3,67 \\
\hline $\begin{array}{l}\text { Will continue to work here because it is a moral obligation to } \\
\text { remain here }\end{array}$ & 4.51 \\
\hline Accepting offers from other workplaces is not justified. & 3.96 \\
\hline $\begin{array}{l}\text { Someone who chooses to live in one workplace is the right } \\
\text { choice }\end{array}$ & 2.36 \\
\hline $\begin{array}{l}\text { Someone who works throughout his career is in one workplace } \\
\text { is the right choice }\end{array}$ & 3.81 \\
\hline Indicator 3: Continuance & 3,77 \\
\hline Variable: Work Commitment & 3,30 \\
\hline
\end{tabular}

Table 4 presents linear regression analysis for hypothesis testing. The effect of organizational learning to employee readiness and work commitment. 
TABLE IV. HYPOTHESIS TESTING

\begin{tabular}{|l|l|l|l|}
\hline Hypothesis & \multicolumn{1}{|c|}{ Relationship p-value } \\
\hline H1 & $\begin{array}{l}\text { Learning Organization -> } \\
\text { Employee Readiness }\end{array}$ & 0.476 & 0.002 \\
\hline H2 & $\begin{array}{l}\text { Learning Organization -> Work } \\
\text { Commitment }\end{array}$ & 0.126 & 0.363 \\
\hline H3 & $\begin{array}{l}\text { Employee Readiness -> Work } \\
\text { Commitment }\end{array}$ & 0.367 & 0.001 \\
\hline
\end{tabular}

Table 3 show that: (1) Learning Organization has significant effect on employee readiness, $(p=0,002)$ (2) Learning Organization has not significant effect on Work Commitment, ( $\mathrm{p}=0,363)$ (3) Employee Readiness has significant effect on Work Commitment, $(\mathrm{p}=0,001)$.

\section{B. Discussion}

As can be seen on Table 5, the results of hypothesis testing show that learning organization has a positive significant effect on employee readiness ( path coefficient $=0.476 ; \mathrm{p}$ value $=$ $0.002)$. Thus, hypothesis 1 was supported. This means that learning organization process implemented by academic staff has an important role in developing employee readiness toward education 4.0. This result supports previous research conducted by Ishak and Mansoor who found a positive and significant relationship between learning organization and academic staff readiness for education 4.0 [3].

Implementation of five discipline from Senge is important to improve academic staff readiness in education 4.0 era [4]. Willingness of academic staff to teach at various times, places and examination model will improve if organization has big effort to enhance that five discipline. In addition, ability of academic staff to provide personal learning, project-based methods and field learning can be improved by implementation of learning organization.

Related to hypothesis 2 , the results of hypothesis testing on Table 3 show that learning organization has a non-significant positive effect on employee readiness (path coefficient $=0.126$; $\mathrm{p}$ value $=0.363$ ). Thus, hypothesis 2 was not supported. This means that learning organization implemented by academic staff has positive effect on work commitment among the academic staff, but it was not significant. This finding is not in line with the findings from previous research, Hanaysha who conducted research online survey from 242 employees at public universities in northern Malaysia found that an academic staff who participates in learning organization will improve their commitment [18].

Although the direct effect of learning organization on work commitment is insignificant, there is still a significant indirect effect on work commitment mediated by employee readiness. This means that a learning organization that can provide employee readiness will have a significant effect on increasing work commitment. Higher education institutions need to apply five disciplines of organizational learning to academic staff in order to have readiness to challenges changes in technology and the environment so that they have commitment to the organization and their work.

In terms of hypothesis 3 , as can be seen on table 3 , employee readiness has a positive significant effect on work commitment (path coefficient $=0.367 ; \mathrm{p}$ value $=0.001$ ). Thus, hypothesis 3 was supported. The results of this study support previous research conducted by Valerie et al [12] showed that Employee readiness has a positive and significant effect on employee commitment of bank employee. Other research conduct by Madsen et al., The findings indicate significant relationships between readiness for change and organizational commitment. When employees are ready for changes caused by technological developments or environmental changes, employees will be committed to their organization, which is reflect by affective, normative and continuance.

There are several things that need to be improved by institutions related to organizational commitment, namely: feeling to be a part of family, sense of belonging and emotionally attached to the organization. Because these three things are the lack of attitude among academic staff.

\section{CONClusion And Future SCOPE}

The findings of this research contribute to the body of knowledge by examining the role of organizational learning in enhancing employee readiness for education 4.0 and work commitment. This study validated the applicability of the measure of Learning Organization Questionnaire for all Schools (LOQS), which developed by Park and Rojewski [19] which was designed to evaluate the extent to which the learning organization disciplines, as proposed by Senge [4] in Indonesia context. The results indicated that learning organization implementation that develops five disciplines: personal mastery, mental models, shared vision, team learning, and system thinking is vital to stimulating and improving employee readiness in education 4.0. In addition, the findings of this research support that learning organization is important to build work commitment. Learning organization has not positive direct impact to work commitment, but it has indirect effect that mediating by employee readiness. This means that organizational learning can increase employee readiness, which will strengthen work commitment.

Future studies need to examine learning organization with different measurement in predicting work commitment of academic staff, which leads to a more accurate impact of learning organization on work commitment. Improvement of studies in employee readiness in education 4.0 is important in the new normal situation because it was in the same perspectives, using technology to doing education or service for student and user in high education.

\section{ACKNOWLEDGMENT}

Thank to Faculty of Administrative Science for giving fund of this study, all of respondents (lecturer of Brawijaya University). 


\section{REFERENCES}

[1] B. Aberšek and A. Flogie, "Evolution of Competences for New Era or Education 4.0," 2017.

[2] E. Dunwill, "Changes That Will Shape the Classroom of the Future: Making Education Fully Technological," E-Learning Ind. https//elearningindustry. com/4-changes-will-shapeclassroom-of-thefuture-making-education-fully-technological, 4AD.

[3] R. Ishak and M. Mansor, "The Relationship between Knowledge Management and Organizational Learning with Academic Staff Readiness for Education 4.0,” Eurasian J. Educ. Res., vol. 20, no. 85, pp. 169-184, 2020.

[4] P.M. Senge, N. Adiarni, and L. Saputra, Disiplin kelima: seni dan praktek dari organisasi pembelajar. Binarupa Aksara, 1996.

[5] E. Abbasi, M. Taqipour, and A.P.D.H. Farhadian, "Learning Organization Discipline in Iranian Higher Education System," J. Educ. Instr. Stud. World, vol. 2, no. 2, pp. 58-68, 2012.

[6] M. Hermann, T. Pentek, and B. Otto, "Design Principles for Industrie 4.0 Scenarios," in 2016 49th Hawaii international conference on system sciences (HICSS), 2016, pp. 3928-3937.

[7] A. Fitriyanto, "Ketidakpastian Memasuki Dunia Kerja Karena Pendidikan," Jakarta: Dineka Cipta, 2006.

[8] I.A.R. Damasanti, "Kesiapan Kerja Ditinjau Dari Motivasi Kerja, Sikap Kewirausahaan, Dan Kompetensi Keahlian Busana Wanita Pada Siswa SMKN Program Keahlian Tata Busana Di Provinsi Bali." Universitas Negeri Malang, 2013.

[9] D. Soumyaja, T.J. Kamlanabhan, and S. Bhattacharyya, "Antecedents of Employee Readiness for Change: Mediating Effect of Commitment to Change,” Manag. Stud. Econ. Syst., vol. 2, no. 1, pp. 11-25, 2015.
[10] S.B. Kurniawan and M.F. Imron, "Seasonal Variation of Plastic Debris Accumulation in the Estuary of Wonorejo River, Surabaya, Indonesia," Environ. Technol. Innov., vol. 16, p. 100490, 2019.

[11] Z.E. Putri, "Pengaruh Partisipasi Anggaran, Komitmen Organisasi, Gaya Kepemimpinan Terhadap Kinerja Manajerial,” ESENSI J. Bisnis Dan Manaj., vol. 4, no. 3, 2014.

[12] M. Valeri, A.R. Matondang, and E. Siahaan, "The Influence of Employee Participation and Employee Readiness to Employee Commitments against Corporate Strategy (Spin off) Through Organizational Support as a Moderating Variable on BPD Banks," Int. J. Res. Rev., vol. 7, no. 2, pp. 56-71, 2020.

[13] C. Argyris, "Personality vs. Organization," Organ. Dyn., vol. 3, no. 2, pp. 3-17, 1974.

[14] M.J. Marquardt, Building the learning organization: A systems approach to quantum improvement and global success. McGraw-Hill Companies, 1996.

[15] M. Dodgson, "Organizational Learning: A Review of Some Literatures," Organ. Stud., vol. 14, no. 3, pp. 375-394, 1993.

[16] S.P. Robbins, "Perilaku Organisasi Edisi 10, Jakarta PT," Salemba Empat, 2006.

[17] N.J. Allen and J.P. Meyer, "The Measurement and Antecedents of Affective, Continuance and Normative Commitment to the Organization," J. Occup. Psychol., vol. 63, no. 1, pp. 1-18, 1990

[18] J. Hanaysha, "Testing the Effects of Employee Engagement, Work Environment, and Organizational Learning on Organizational Commitment," Procedia-Social Behav. Sci., vol. 229, pp. 289-297, 2016.

[19] J.H. Park and J. Rojewski, "The Learning Organization Model across Vocational and Academic Teacher Groups," Career Tech. Educ. Res., vol. 31, no. 1, pp. 23-48, 2006. 